\title{
Metal Highlights
}

\section{METALS SOLUTIONS}

\section{Eathodic corrosion protection for hot stamping}

With GammaProtect, ThyssenKrupp Steel Europe has developed a new anti-rust finish that is suitable for hot stamped components. GammaProtect is an electrolytic coating with a high melting point that withstands the temperatures of hot stamping. As well as protecting against scaling it also provides active cathodic corrosion protection along with the conventional galvanizing of cold forming steels. The coating therefore expands the range of applications for hot stamping to include parts in the wet area of the car body particularly at risk from corrosion.

The composition of GammaProtect increases the melting point of the coating to over 870 degrees, and the zinc content is high enough to ensure it retains its cathodic corrosion protection properties. The coating is so resistant that it can tolerate timing variations in the production cycle, which ensures process stability. Besides, sheet coated with GammaProtect can be heated at significantly faster rates, shortening holding time in the furnace by up to 20 percent compared with current production parts. Hot stamping - or hot forming - is enjoying a boom in the auto industry because as well as meeting strict safety standards it also helps reduce vehicle weight. The interest of GammaProtect is demonstrated primarily in direct hot stamping, where steel sheet is first heated to around $900{ }^{\circ} \mathrm{C}$ and then immediately stamped and simultaneously cooled in a special die. The rapid cooling produces components with strengths of up to $1650 \mathrm{MPa}$, permitting the production of parts with thinner walls and lower weight.

\section{PLANTS AND EQUIPMENTS}

\section{Badische Stahlwerke upgrades mill}

Badische Stahlwerke GmbH, Kehl, Germany has selected Siemens VAl to undertake an extensive upgrade for its wire rod rolling line. The automation system of the two-strand wire rod mill will be modernized, and two new rod outlets will be installed.

Siemens VAl's upgrade of the Badische Stahlwerke wire rod mill, which mainly produces base material for concrete reinforcing bar, will result in an increase in production capacity and a broader spectrum of qualities and sizes due to increased automation and the possibility of thermomechanical rolling.

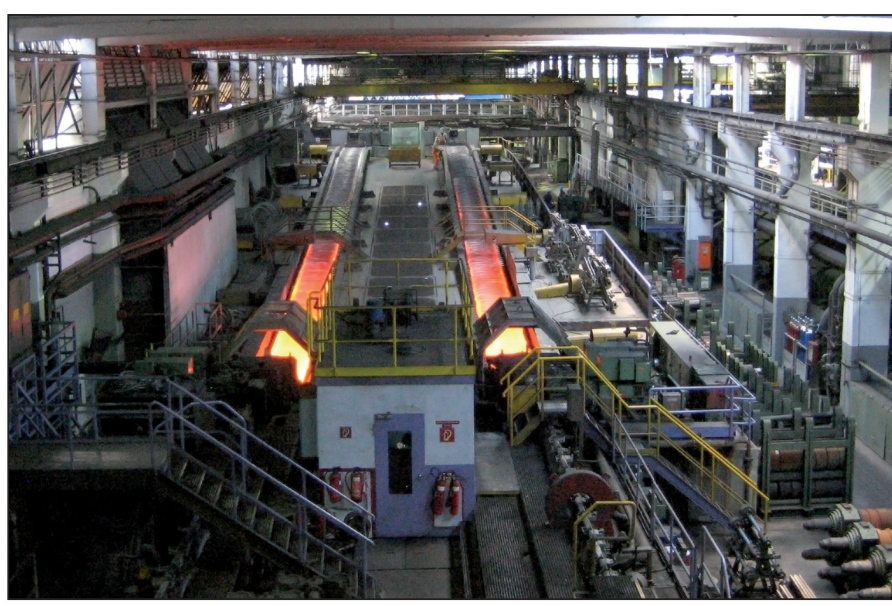

Wire rod mill of Badische Stahlwerke GmbH (BSW) in Kehl, Germany. The mill will be thoroughly modernized by Siemens. Photo courtesy of BSW

To minimize downtime, the upgrade will be implemented in three phases in from 2011 to 2014 during scheduled annual shutdowns. The first phase involves replacing the existing automation system of the 13 stands of the roughing and intermediate mill with the Siroll LR automation system, based on Siemens PCS7 software, to provide fully automatic control and easier maintenance.

In the second phase, Siemens VAI will erect the two new rod outlets, each with a six-stand and four-stand Morgan No-Twist mill, 10 Morgan Intelligent Pinch Rolls, high speed trimming shears, Morgan High Speed Laying Heads, Morgan Stelmor conveyors and a vertical coil handling system in preparation for the third phase, when the new equipment will be connected to the existing mill and commissioned in early 2014. The Siroll LR automation system, extended to the two new rod outlet control systems with mechatronical packages, will offer an integrated solution throughout the line.

Rod speed guarantees are up to 110 meters per second, and the coil handling system will produce a coil every 20 seconds, resulting in a production rate of up to 300 tons per hour. Siemens is responsible for all erection and commissioning of the mechanical and electrical equipment in a turn-key operation. The planning and execution of related infrastructure works and civil engineering, as well as the installation of auxiliary facilities such as the water system, will be undertaken by BSW.

\section{AIC and Morgårdshammar to supply new Mittal plant}

In cooperation with the Swedish company Morgårdshammar $A B$, part of Danieli Group, industrial automation systems specialist AIC has been awarded the electrical and automation part of a complete turnkey project for the supply of a new "green field" Bar \& Wire Rod Mill for Mittal Corp. Limited. 
The new plant will be realized in Indore - Madhya Pradesh and will be suited to produce stainless steels and special steel products. The electrical supply is a totally integrated Rockwell architecture (Drives, PLCs and SCADA software) and includes both power and automation panels as well as AC\&DC motors, PLCs and HMI systems, cold test, hot start-up, hot and performance test.

As far as Danieli Morgårdshammar is concerned, the supply starts from the billet charging, reheating furnace, a reversing roughing stand, associated front and back mechanization, a continuous mill train of $\mathrm{P} 600$ horizontal and vertical stands, a low reduction wire rod block P800 new Delta series followed by laying head and coil facilities. The bar line constists in a Quenching and Tempering Bar (QTB) system followed by the dividing hear, cooling bed and cut to length system associated to a bundling system.

Mittal Corp. Ltd. is a manufacturer with operations in the central region of India and customers in the $500 \mathrm{~km}$ radius. It produces stainless steel products as rounds, wire rods and flats which are mostly used for the automotive industry, utensils and medical equipments. The designed capacity of the mill is 150,000 tpy and will be able to produce sizes from $5.5 \mathrm{~mm}$ up to $75 \mathrm{~mm}$ in Stainless Steel (AISI 200, 300, 400 series), Mild Steel, Medium Carbon \& Carbon Steel and Alloy steel, starting from a billet size of $160 \mathrm{~mm}$ square with a weight up to 1,2 tons.

\section{Severstal Columbus continues expansion}

Severstal North America, started its Phase II expansion in Columbus, Mississipi. The $\$ 550$ million expansion project at Severstal Columbus must increase annual steel production to 3.4 million tons, doubling the plant's steelmaking capacity. The expansion project included a second electric arc furnace, ladle metallurgy furnace, caster, tunnel furnace, and hot-dip galvanizing line. A wide heavy gauge push pull pickle line was also included in the Phase II project. With Phase 1 completed in 2007 at cost of $\$ 880$ million, Severstal Columbus is in the vanguard of the "mini-mill" movement utilizing technology that recycles scrap steel into product suitable for the auto industry, pipe and tube, appliances and other applications. The operation currently employs over 650 employees.

"The addition of Phase 2 allows us to increase sales to the market sectors where we were not actively present. We gained broad capabilities in heavy gauge pickled and galvanized products which we are now able to offer to the customers in both master coil and sheets or slit-to-ustomer order", said Sergei Kuznetsov, CEO of Severstal North America.

\section{NLMK revamps hot rolling facilities}

Following its reconstruction, NLMK has started hot testing and produced the first slab at its reheating furnace No. 3, a facility for heating slabs prior to hot rolling. Furnace capacity has increased 23\% to 320 tonnes per hour. The revamped furnace must allow a $35 \%$ reduction in specific fuel consumption, decreased metal loss, lower air emissions, and stabilized rolling.

Reheating furnace No. 3 is the third new type facility at NLMK's hot rolling operations in Lipetsk (reheating furnace No. 5 was revamped and commissioned in 2004, reheating furnace No. 4 - in 2007). The technological capabilities of these units enable them to process both carbon and transformer (grain-oriented) steel slabs.

The project forms part of the action plan aimed at the reconstruction of Hot Strip Mill 2000 equipment with a view to expanding hot-rolled steel production at NLMK's Lipetsk site to 5.7 million tonnes of high quality steel by improving the productivity of existing equipment. This project, worth approximately RUR1.9 billion, has been implemented jointly with CMI (Belgium) as part of Stage II of NLMK's Technical Upgrade Program.

\section{Aluminum forging plant in China to increase production capacity}

Kobe Steel plans to increase the production capacity of its subsidiary in China that makes aluminum forgings for automotive suspensions. Kobe Steel will install an additional 6,300-metric-ton mechanical forging press, as well as melting and casting equipment at Kobe Aluminum Automotive Products (China). Total investment is anticipated to reach 4.5 billion yen and operations are to begin in March 2013.

Kobe Aluminum Automotive Products (China) (or KAAP China) was established in September 2010 in Suzhou, Jiangsu Province. The first phase of the plant is currently under construction and is anticipated to begin volume production in August 2012.

\section{Vallourec commissions threading facility in North America}

Vallourec will construct a new threading facility in Youngstown, Ohio, through its subsidiary VAM USA LLC. This decision is supported by the development of unconventional Oil \& Gas drilling of shale resources, driving increased demand for connections. The new VAM facility will be located next to Vallourec's existing and soon to be commissioned pipe mills and close to customers operating in both the Marcellus and Utica shale areas. It will complement the VAM USA manufacturing facilities in Houston, Texas and enable the group to expand its finished goods offer combining pipe and connections. Representing an investment of US\$ 57 million ( $€ 42$ million), the new production facility will ramp-up in phases, starting with one manufacturing line operating in mid-2012, and multiple lines operating by the end of 2013. 


\section{Interpipe begins cold tests for new melting complex}

Interpipe has started cold tests, in cooperation with general contractor Danieli, at the new electric steel melting complex, Interpipe Steel, located in Ukraine. The total investment is USD \$700 million. Cold tests provide stage-by-stage checks of all the sites, equipment and mechanisms of the mill in "idle" operation. The main task of each stage is to test the readiness of main and supplementary equipment, infrastructure objects (electric, water and pipeline systems) as well as the technological preparedness. The final stage of the cold tests will be the work checks for the arc furnace.

Interpipe Steel is currently $90 \%$ complete. Construction of the main building in the complex, scrap yard, ferroalloy and particulate materials plant, as well as the installation of the continuous casting machines have all been completed. The tests of the electric supplies are complete, and the construction of the scrap yard, electric arc furnace, ladle furnace and vacuum degasser are almost ready. Hot tests will follow; exploitation tests of Interpipe Steel are planned for the first quarter of 2012.

\section{ArcelorMittal invests at Industeel facility}

ArcelorMittal inaugurated on 18 November 2011 a new facility of Industeel Belgium. The project required an investment of 28.7 million euro and involved more than 90 companies and 500 workers. The new facility will have a production capacity of 100000 tons of special plates for oil \& gas, mining, and other industries. The production lines have been running at full capacity since May 2011. More than 50\% of the steel plates produced in Charleroi are exported outside of Europe, particularly to Asia.

Previously known as "Fabrique de Fer", Industeel Belgium in Charleroi employs 950 people and is specialised in plate fabrication from thin gauge $(5 \mathrm{~mm})$ up to thick gauge $(150 \mathrm{~mm})$ with a maximum plate weight of 16 tons. Industeel Belgium manufactures between 150000 and 220000 tons of special steel plates per year. Notably Industeel Belgium produces quarto plates used for liquefied natural gas storage tanks.

\section{= Quick-exchange pinch-roll cassette for hot-strip mill downcoilers}

During the coiling of hot strip, deposits forming on the pinch rolls have to be removed at frequent intervals in order to prevent damage to the roll surface, which can impair strip quality. The pinch rolls also have to be refurbished at regular intervals, depending on the steel

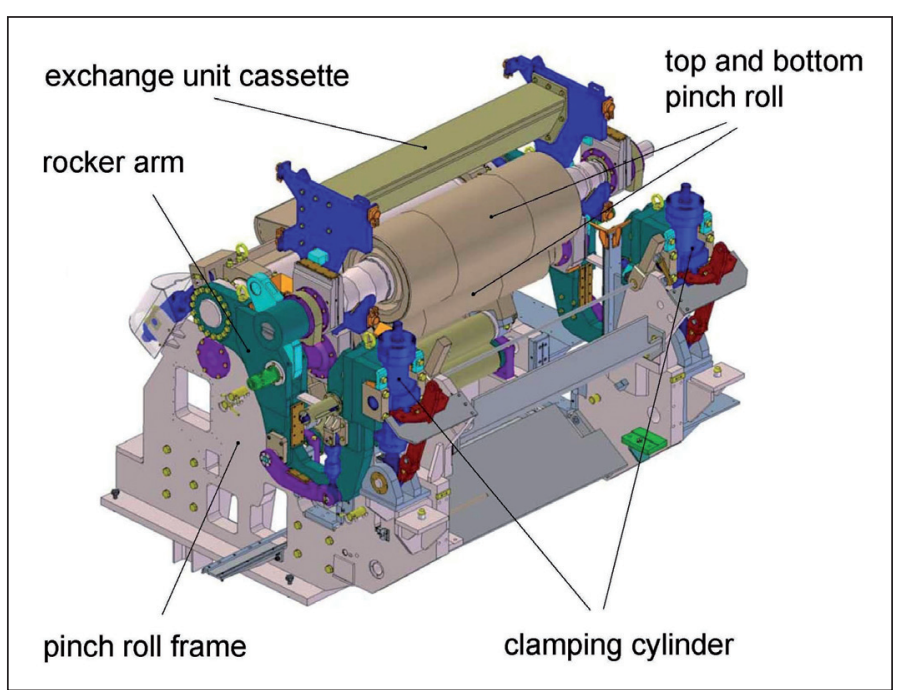

The new pinch-roll quick-exchange unit from Siemens VAI reduces roll-replacement times from up to eight hours down to just ten minutes.

grade rolled and the length of time that the pinch rolls have been in use. Siemens VAI Metals Technologies now offers hot-strip mill operators a new method for changing the pinch rolls in downcoilers. The pinch-roll unit, designed as a quick-exchange cassette, can be replaced within just ten minutes without additional interruption of production.

That saves up to eight hours typically required when applying conventional solutions. The rolls can be cleaned and refurbished offline, thereby enhancing both strip quality and personnel safety. The short time required to replace rolls now allows an exchange to be synchronized with specific operational requirements, such as a change in the grade of steel to be rolled or the specific strip quality requirements.

The capability to change the pinch rolls quickly also enables the cleaning and refurbishing intervals to be ideally timed to optimize the roll-surface condition and length of service life. An optional surface testing system supports the operator to achieve this.

\section{Nippon Steel / Kobe Steel: dust recycling joint venture begins operations}

Nippon Steel Corporation and Kobe Steel, Ltd. announce that their steel mill dust recycling plant began commercial operation. Both companies use steel mill dust and iron ore fines from their steel mills as raw materials to produce direct reduced iron (DRI) and to recover zinc. As part of the objectives to deepen and expand their alliance, the two companies decided in October 2008 to establish a joint venture to recycle steel mill dust and turn it into direct reduced iron. Construction of the plant began in May 2010; named Nittetsu Shinko Metal Refine, it is 
located in Himeji, Hyogo Prefecture. Treatment capacity is approximately 220000 metric tons per year. Nittetsu Shinko Metal Refine utilizes Kobe Steel's Fastmet process. In this process, steel mill dust is heated to a high temperature in a doughnut-shaped rotary hearth furnace (RHF) and quickly undergoes reduction to make DRI. At the same time, the zinc in the steel mill dust is recovered. The DRI can be used as an alternative to purchased scrap and iron ore as the main raw material, and the recycled zinc can reduce the use of zinc ore. Recycling also promotes zero emissions.

\section{TMK commissions thread line for casing}

A new thread line for casing has been commissioned at Orsky machine building plant, which is part of TMK's oilfield services division. The first product manufactured on the new line was a casing pipe (diameter $168.28 \mathrm{~mm}$ ) with TMK FMC and TMK GF premium connections, as well as a casing pipe (diameter $244.83 \mathrm{~mm}$ ) with a TMK GF connection. The design capacity of the new thread line is 24000 tonnes per year of casing, which will cover a diverse product mix.

Production of casing with gastight connections at Orsky machine building plant must allow the company to offer new products for oil and gas well infrastructures.

\section{Essar Steel commissions Corex module}

Essar Steel, India, has commissioned a Corex module, with a capacity of 0.87 MTPA, as part of its plans to increase production capacity from 4.6 MTPA to 10 MTPA at its Hazira complex. It has earlier commissioned a blast furnace and a DRI module; a second Corex module of 0.87 MTPA is expected to be commissioned shortly. The overall expansion including downstream facilities at Hazira is being done at a cost Rs.17 000 crores.

\section{New special steel rolling mill for Vardhman}

Vardhman Special Steels, an India-based producer of special and alloy steels, has choosen Danieli Morgårdshammar Sweden for a new bar mill for the production of Special and Alloy Steel.

The project consists in the supply of the technological equipment, starting from the exit of the reheating furnace down to the bundle handling system, including the electrical and automation system. This includes a new generation of the shiftable housingless rougher P600 series and a continuous rolling mill arranged in horizontal / vertical configuration.
With this new installation Vardhman Special Steels Company will increase the production up to 150000 tpy and expand the range of products with rounds from $16 \mathrm{~mm}$ up to $120 \mathrm{~mm}$, round corner squares from $40 \mathrm{~mm}$ to $125 \mathrm{~mm}$ and hexagons from $15.5 \mathrm{~mm}$ to $60 \mathrm{~mm}$. Start-up of the new mill is scheduled at the third quarter of year 2012.

\section{Novelis extends aluminum rolling mill in Ulsan}

Siemens VAI Metals Technologies has received an order from Novelis Korea Ltd. to extend its aluminum rolling mill in Ulsan. To this end, a three-stand finishing line will be added to the plant. The project is aimed at boosting capacity and enabling future production of high-grade aluminum strip. The order volume is in the two-digit euro millions. The first strip is already to be rolled in July 2013.

Up to now, the aluminum hot rolling mill operated by Novelis in the Korean city of Ulsan consisted of a single reversing stand with two coilers and the necessary secondary systems. The rolling mill was equipped by Siemens in 1993.

Siemens is supplying the mechanical and electrical equipment for the new, three-stand tandem rolling mill including a coiler and a coil handling system. In the future, the existing reversing stand will function as a roughing mill. Lightweight cropping shears will also be installed in the entry to the finishing line.

\section{Severstal makes $\$ 350 m$ investment in Balakovo mill}

OAO Severstal has invested approximately $\$ 350$ million in the construction of a new long product mini-mill at Balakovo, in the Saratov Region, Russia. The total investment in the long product mini-mill must be approximately $\$ 700$ million.

The Severstal Balakovo long product mill is a metallurgical mini-mill which will primarily service the building and construction industries. The mini-mill is scheduled to be commissioned in the second quarter of 2013, and must produce more than 1 million tons of long products per year.

\section{Tata Steel expects growing wind turbine jacket demand}

Tata Steel is investing $£ 2$ million in its Hartlepool tube works and has forged a supply deal with German steel tube producer Eisenbau Krämer (EBK) to increase its product and service offering to the offshore 
renewable energy sector. Tata Steel expects growing activity in the renewables sector to require large volumes of jacket fabrications for wind tower structures. The Hartlepool development will establish a central supply base for steel tubular sections to be used in the fabrication of wind turbine steel foundation structures. Work on the site is scheduled to be complete by Spring 2012.

Components will be manufactured from tubulars at the new facility and prepared for welding into the finished structures. Preparation work will include cutting-to-length, welding, shot-blasting, coating and endprofiling. Materials will then be stored for shipment in kit form to fabricators in the UK and mainland Europe using local deepwater ports and the UK rail network.

Under the supply agreement tubes from $400 \mathrm{~mm}$ diameter upwards will be produced by Tata Steel and EBK from plate manufactured by Tata Steel's plants in Scunthorpe or Dalzell.

\section{NLMK commissions continuous casting machine}

The first slabs have been cast at Novolipetsk's (NLMK's main production site in Lipetsk) newly revamped 2.5 mtpa continuous casting machine (CCM-8). The objective of the CCM-8 reconstruction project was to increase output, expand the product mix and ensure a consistently high quality of concast slabs for further conversion into flats.

Currently the maximum thickness of slabs produced by continuous casting machines in Russia is $300 \mathrm{~mm}$. Following the CCM-8 revamp NLMK can produce slabs with thicknesses of up to $355 \mathrm{~mm}$ for further conversion into thick plate, notably at NLMK's subsidiaries in Europe, DanSteel and Clabecq.

As part of the project, the CCM was fully revamped, ladle turrets were replaced, and closed water cooling systems were installed. CCM-8 uses a dynamic secondary cooling model to improve the surface quality and internal structure of the semis. The facility is equipped with an advanced automation and instrumentation system.

\section{Erasteel opens powder metallurgy facility in Sweden}

Erasteel, a subsidiary of Eramet has inaugurated a new gas atomizing tower at its Söderfors plant in Sweden. Erasteel produces high speed steel through the process of gas atomized powder metallurgy. Thanks to this new facility, Erasteel means to extend its product range to new steel grades, such as stainless steel, nickel and cobalt alloys, and bring to the market new solutions in the form of gas atomized powders of highly alloyed steels. This must also allow ERAMET to reach new markets - tooling, energy and in particular oil and gas. This new equipment represents an investment of around $20 \mathrm{M€}$. The plant's capacity after this investment will reach 14000 tons per year.

In 2011, Eramet Alloys is commissioning four facilities (powder metallurgy in Sweden, titanium, aluminium and nickel alloys in France) for a total capital expenditure of around $120 \mathrm{M} €$. Eramet Alloys continues to focus its development on new materials. Eramet produces alloying metals, particularly manganese and nickel, used to improve the properties; and special steels and alloys used in industries such as aerospace, power generation and tooling.

\section{Alcoa expands Davenport plant}

Alcoa will expand its Davenport, lowa rolled products plant to meet demand from the automotive market, inparticular automotive original equipment manufacturers (OEMs) switching to aluminum products.

Alcoa Davenport Works produces aluminum sheet and plate for a variety of industries. Materials produced at the plant are used in aerospace and defense, passenger vehicles (cars and light trucks), commercial truck and rail transportation and the industrial market. The expansion, which will entail an investment of approximately $\$ 300$ million, will create an additional 150 full time jobs in the facility once completed, bringing total employment to more than 2,300 jobs. The expansion must be completed by the end of 2013 .

The Alcoa 951 technology is used to improve adhesive bonding for vehicle assemblies. The process is used as a pretreatment for aluminum alloy sheet, extrusions and castings to improve bonding performance. In customer trials, tests have shown it as being four to nine times stronger than titanium zirconium applications used in the automotive industry.

A study of automakers by Ducker Worldwide, released earlier this month, showed automakers will increase their use of aluminum from 327 pounds in 2009 to 550 pounds in 2025. For 2012 model cars, the use of aluminum has reached an all-time high of 343 pounds per vehicle, a five percent increase. According to OEMs surveyed in the study, aluminum use as a percent of the overall automotive materials mix is expected to double by 2025 to 16 percent.

\section{= Siemens VAl Metals Technologies receives third Finex order from Posco}

Siemens VAI Metals Technologies received an order from Posco Engineering \& Construction Co., Ltd. (Posco E\&C), a subsidiary company of the Korean steel producer Pohang Iron and Steel Co. Ltd. (Posco), for engineering and the supply of proprietary equipment for a Finex $2.0 \mathrm{M}$ 


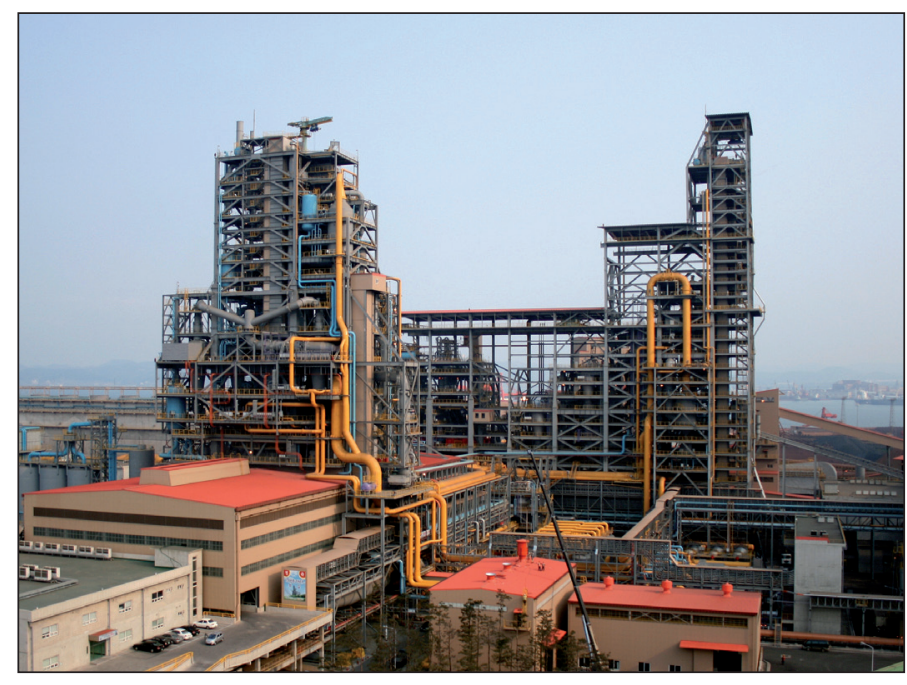

View of existing Finex 1.5 M plant, Pohang, Korea (left: melter gasifier tower, right: fluidized bed reactor tower).

plant. This ironmaking facility, which will be built at Posco's Pohang steelworks, will produce some 2 million tons of hot metal on the basis of directly charged low-cost iron ore fines and predominantly noncoking coal. The order value for Siemens is a medium two-digit-million euro figure. Upon completion of the new Finex plant scheduled for mid-2013, a total of approximately 4 million tons of hot metal will be produced per year using the Finex process at Posco.

The project scope for Siemens VAI includes the supply of basic and detail engineering for the main plant area that comprises the melter gasifier, the fluidized-bed reactor system and the auxiliary facilities of the hot-compacting iron $(\mathrm{HCl})$ plant. Advisory services for erection and commissioning are part of the project scope.

Compared to the company's two existing Finex plants, the number of fluidized bed reactors will be reduced from four to three. This and the installation of new technological packages such as a pneumaticcharging system must reduce the specific investment costs for the new Finex plant by about $15 \%$. Hot metal from all three Finex plants will be processed to high-quality steel in Posco's LD (BOF) steel mills. Finex export gas is used for the generation of electrical energy in a Poscoowned combined-cycle power plants.

\section{= Tata Steel invests $£ 2.4 \mathrm{~m}$ to capture and recycle energy from CAPL line}

A new investment at the Port Talbot steelworks is set to improve the competitiveness of the site, generate over $1 \mathrm{MW}$ of energy, and reduce carbon dioxide emissions by 6000 tonnes per year.
The CAPL (Continuous Annealing Process Line) waste heat recovery project will generate steam and make use of a turbine being installed as part of Port Talbot's $£ 53$ million BOS (Basic Oxygen Steelmaking) Plant Evaporative Cooling Scheme.

The CAPL project will be carried out between July and December 2012 to coincide with the BOS Plant project, as well as with the $£ 185$ million project to rebuild Port Talbot's Blast Furnace No 4.

The CAPL line at Port Talbot was built in 1999. Port Talbot Hub Director Jon Ferriman said: "Times are very tough in the steel industry at the moment. However, we are committed to our capital expenditure programme to further improve the competitiveness of Welsh steelmaking. By increasing our power generating capacity we are improving our energy efficiency and there is also a significant indirect impact on carbon dioxide emissions".

\section{Metinvest launches blast furnace at Yenakiieve Steel}

Steel and mining group Metinvest has commissioned a new blast furnace at its Yenakiieve Iron and Steel Works subsidiary. The furnace will add 1.2 million tonnes of capacity to the plant's annual hot metal production, which will eventually total 3 million tonnes of pig iron per year. Construction of the BF-3furnace required an investment of more than US \$220 million.

The new BF-3 is one the plant's largest facilities, and differs from the other two blast furnaces operating at Yenakiieve Steel. The furnace's bellless charging unit, made by Paul Wurth (Luxemburg), is meant to reduce coke consumption by five percent while increasing the blast furnace's productivity by five percent.

A new refractory lining applied to the blast furnace hearth walls is designed to quadruple the service life of the furnace, aiming at 15 years of maintenance-free operation. The furnace is also equipped with a Paul Wurth gas cleaning unit.

Technological process control at BF-3 is based on a Siemens VAI (Austria) industrial control system. This integrated control network processes more than 5,000 validation parameters.

The Industrial Control System also encompasses the heat and power plant steam and air blowing station, which was modernized along with the BF-3 construction project.

At the Heat and Power Plant, a turbine and compressor unit (Turbine Air Blower No. 6) made by CKD Nove Energo (Czech Republic) and a recycled water supply unit with two ventilated cooling towers and Germanmade pumping equipment were installed. 


\section{Nyrstar: new evaporator unit}

CMI Services has just delivered an evaporator block to metals supplier Nyrstar. With a total weight of around 16 tons, this equipment will be installed in a $900^{\circ} \mathrm{C}$ flue gas system within a metallurgical furnace at Nyrstar's Auby site (northern France).

\section{JSW Steel orders continuous slab caster from Siemens VAI}

Steel producer Jindal South West Steel Ltd. (JSW Steel) has ordered a new continuous slab caster from Siemens VAI Metals Technologies for its steel works in Toranagallu, Karnataka State, India. As with caster No. 3 , also supplied by Siemens, the new casting plant will be equipped with DynaGap Soft Reduction.

This solution enables the taper and thickness to be controlled automatically at every point of the strand guiding system to create the basic conditions for high internal slab quality. The continuous slab caster will have an annual production capacity of 1.4 million tons and is to be commissioned in the middle of 2013.

The new continuous slab caster (caster No. 4, in steelworks No 1) for the JSW Steel Works in Toranagallu will be able to cast slabs with thicknesses between 220 and 260 millimeters, and widths between 800 and 1,600 millimeters.

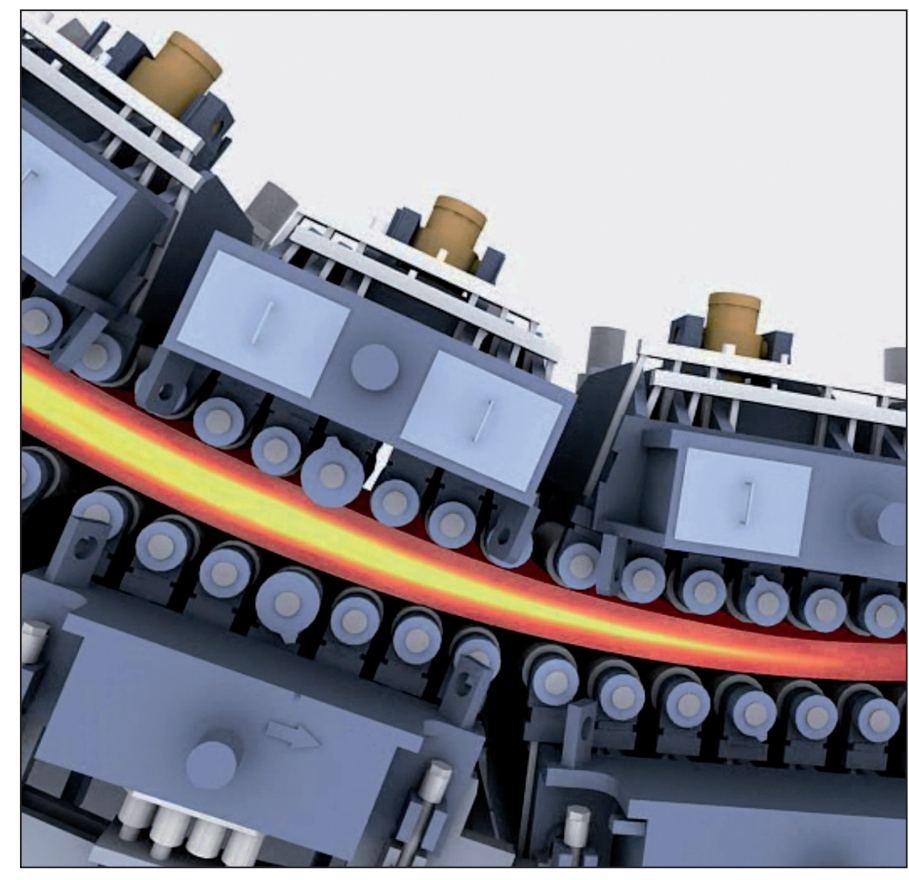

DynaGap Soft Reduction enables the taper and thickness to be controlled automatically at every point of the strand guiding system.
It will produce carbon steel, micro and low-alloy, as well as HSLA (high-strength low-alloy) steels, which will be further processed into sheets, strips and pipes. The new continuous slab caster will be equipped with DynaGap Soft Reduction, like caster No. 3 which was supplied by Siemens and then modernized in 2009.

\section{Baotou Steel Union orders heavy section mill}

The Chinese company Inner Mongolia Baotou Steel Union Co. Ltd. has placed an order with SMS Meer for the supply of a heavy section mill. With this new mill Baotou will be able to produce beams with web heights from 200 to $1000 \mathrm{~mm}$, rails from $52 \mathrm{~kg} / \mathrm{m}$ to $75 \mathrm{~kg} / \mathrm{m}$ and Ushaped sheet piles up to $600 \mathrm{~mm}$.

Thanks to the CCS (compact cartridge stand) roll stands and a 9-roller CRS (compact roller straightener) straightener, quick section changes are possible. The mill has a capacity of 1.2 million $t / a$.

The scope of supply includes the planning and engineering, the core technological equipment, training of the customer's personnel, the supervision of erection, and commissioning of the plant, scheduled for the end of 2012.

\section{ENVIRONMENTAL OUTLOOK}

\section{Severstal to reduce atmospheric emissions at the Cherepovets steel mill}

Severstal announces the launch of an environmental project aimed at reducing atmospheric emissions at the Cherepovets steel mill, part of the Severstal Russian Steel division.

Following a tender process, Severstal has signed an agreement with Siemens VAI Metals Technologies to supply and install a system for capturing emissions from plant converters. The system will be installed over the next four years.

The new system will be installed alongside the Cherepovets Steel Mill's existing converter process and will include, amongst other things, new bag filters, smoke exhausts, a compressor station, a package transformer and distribution substation, an automated process control system, and a dust removal system. Severstal's will invest up to 3 billion rubles (\$US 96 million) over the next four years in the project. 


\section{New deduster at ArcelorMittal Ostrava}

Three months before the scheduled date, ArcelorMittal Ostrava has completed the installation of a new deduster system at its sinter plant. The investment of one billion Czech crowns must cut dust emissions from the Sinter Plant North to less than $20 \mathrm{mg} / \mathrm{m}^{3}$ (from the present $50 \mathrm{mg} / \mathrm{m}^{3}$, which is the current legal limit). The total dust emissions from sintering will drop by 270 tons per year.

The performance textile filters will catch 70 percent more dust particles than the current electrostatic filters. Mufflers installed in the huge pipes will help to reduce the noise generated by the round-the-clock filter operation by $15 \%$. The system used in ArcelorMittal Ostrava has an added reactor, which makes it possible to capture not only dust particles, but also up to $60 \%$ of all sulphur dioxide and dioxins.

The new deduster is basically a vacuum cleaner : combustion products are siphoned off from electrostatic filters onto a special textile, which catches the dust particles. When the textile filter is covered with a layer of dust, it is shaken to get the dust off into a container; the dust is then disposed of. The technology also contains a muffler with an inner system of noise-dampening segments, and a reactor, in which precise dosage of calcium hydroxide reduces the sulphur oxide emitted into the atmosphere in combustion products. Lignite coke is used to remove toxic dioxins.

The contract with the project contractor Lühr Filter (Germany) was signed in 2008. In 2009, the project was in preparation and the construction of the deduster in the sinter plant commenced in February 2010. Building and assembly was also subcontracted to local companies including, VS-Invest, Elektromont Brno, Hutní projekt Otrava and ST2 LLC D/B/A Sound Technologies.

\section{NLMK's sinter plant cuts dust emission by $20 \%$}

NLMK is currently revamping the central dust collection systems at sintering machines Nos. $3 \& 4$ at its sinter plant in Lipetsk. The introduction of a new type of electrostatic precipitator by Alstom Power must reduce residual dust content in exhaust air almost fourfold. Total dust emissions from the Sinter Plant are due to decrease almost 20\%.

Since the launch of its Technical Upgrade Program in 2000 the company has implemented around 250 projects at its Lipetsk site worth a total of RUR12.3 billion aimed at lowering industrial emissions. As a result, emissions at the site have been reduced by $22 \%$.

Alongside the projects at the Sinter Plant, NLMK is currently revamping the gas cleaning systems at its steelmaking facilities which will allow reducing graphite emissions.

\section{ECONOMY WATCH}

\section{JFE Steel to integrate its electric furnace operators}

JFE Steel Corporation announced plans to integrate four group companies with electric furnace-based production operations - JFE Bars \& Shapes Corporation, Daiwa Steel Corporation, Tohoku Steel Corporation and Toyohira Steel Corporation - on April 1, 2012. As the business environment in Japan grows increasingly severe due to sharp falls in the demand for construction steel materials, JFE Steel has determined that integrating its electric furnace operations will enable the group to remain a viable producer of reinforcing steel bars, thereby helping to ensure sustainable growth going forward.

Among the group's electric-furnace operations halted by the Great East Japan Earthquake, Tohoku Steel will not resume production but will retain its sales function. Products will be supplied to Tohoku Steel by JFE Bars \& Shapes Kashima Works in Ibaraki Prefecture and Daiwa Steel Tobu Works in Saitama Prefecture, both of which manufacture reinforcing steel bars. JFE Bars \& Shapes Sendai Works in Miyagi Prefecture, which also had to halt production, will restart its steel bar plant in mid-July and wire rod plant in early August. The steelmaking plant and slabbing mill will come online sequentially in mid-August, and overall production is expected to return to pre-earthquake levels by October.

\section{Ryerson acquires Turret Steel}

Chicago-based distributor and processor of metals Ryerson, has acquired Turret Steel Industries, and Sunbelt-Turret Steel. The acquisition also includes Turret-affiliated companies Wilcox Steel and Imperial Logistics. Turret and its affiliates generate annual revenues of approximately $\$ 130$ million. In addition to its Pittsburgh headquarters Turret has service centers in Chicago and Warren, Ohio. Turret is primarily a distributor of special bar quality (SBQ) carbon and alloy bar stock focused on bar sizes of less than six inches in diameter. Ryerson has now completed five acquisitions in the last two years, acquiring Houston-based Texas Steel Processing in January 2010; Mobile, Ala.-based Cutting Edge Metal Processing Inc. in May 2010; Houston-based SFI-Gray Steel Inc. in August 2010; and Streetsboro, Ohio-based Singer Steel in March 2011.

Earlier this month Ryerson announced expansions of its Atlanta and Little Rock, Ark. operations with added capabilities in long products and fabricated plate. The company also recently opened new North American service centers in Salt Lake City, Tijuana, Houston and Eldridge, lowa, and also added a new service center in Suzhou, China. 